\title{
Agricultural Information Needs of Rural Women Farmers in Nkonkobe Municipality: The Extension Challenge
}

\author{
Shehu Folaranmi Gbolahan Yusuf ${ }^{1}$, Patrick Masika ${ }^{2} \&$ David Ikponmwosa Ighodaro ${ }^{3}$ \\ ${ }^{1}$ Department of Agricultural Economics and Extension, University of Fort Hare, South Africa \\ ${ }^{2}$ Agricultural and Rural Development Research Institute (ARDRI), University of Fort Hare Alice Campus, South \\ Africa \\ ${ }^{3}$ Department of Agricultural Economics and Extension, University of Fort Hare Alice Campus, South Africa \\ Correspondence: Shehu Folaranmi Gbolahan Yusuf, Department of Agricultural Economics and Extension, \\ University of Fort Hare, South Africa. E-mail: 201103255@ufh.ac.za
}

Received: December 19, 2012 Accepted: February 5, 2013 Online Published: April 15, 2013

doi:10.5539/jas.v5n5p107

URL: http://dx.doi.org/10.5539/jas.v5n5p107

\begin{abstract}
Access to agricultural information is vital for improving food security at the village level. This study accessed the agricultural information needs of women farmers in Nkonkobe Municipality of the Amathole District, Eastern Cape Province, South Africa. Data was obtained from 118 households. The women farmers were identified from four villages using the snowball sampling technique. Findings revealed that backyard gardening $(87.2 \% ; n=103)$ was common in addition to the rearing of indigenous chicken $(65.2 \% ; n=77)$ to complement food security. Most $(80.5 \% ; \mathrm{n}=95)$ were confronted with weed problems after applying cow dung as manure. There was a high report $(70.3 \% ; \mathrm{n}=83)$ of insect attack on leaves of cabbage, spinach and carrot, while seed dormancy was low $(24.58 ; n=29)$. Problems of fowls' theft $(66.95 \% ; n=49)$ and fowl predators $(40.68 \% ; n=48)$ were common. More than average $(54.2 \% ; n=64)$ depends on friends, neighbors and farmers' colleagues for agricultural information but the majority $(99.1 \% ; \mathrm{n}=117)$ preferred extension workers coupled with farm demonstration for agricultural information. The study identified the importance of farmer-to-farmer model of technology transfer among farmers. It is recommended that farmer-to-farmer model could further be investigated to complement efforts of the extension services towards providing agricultural information to the smallholder farmers.
\end{abstract}

Keywords: agricultural information, rural women farmers, extension services, needs

\section{Introduction}

Women farmers play a significant role in the food security of households. In sub-Saharan Africa, women do about $80 \%$ of the farm labor (Bill and Melinda Gates Foundation, 2012). Banji and Okuade (2005) attributed 60\% of the farm labor force to women who produce $80 \%$ of food and earn $10 \%$ of the monetary income but own just $1 \%$ of the farm assets. The report of FAO (2011) indicated that if women had the same access to productive resources as men, they could increase yields on their farms by 20-30\%, lifting 100-150 million out of hunger. Furthermore, FAO (2011) reported that equal access to the resources by both male and female farmers will increase the total agricultural output in the developing countries by $2.5-4 \%$, thereby contributing to both food security and economic growth. Thus, any effort designed to improve South Africa's agriculture generally and the lives of its smallholder farmers in particular must take cognizance of women's roles in livelihoods and food security

Information, according to Belkin and Pao (1989), is the product that emanates from processing, manipulating and organizing data in a way that creates value to the knowledge of the person receiving it. Though Stanley (1990) likened information as one of the basic necessities of life after air, water, food, and shelter, Rezvanfar et al. (2007) indicated that information is needed because of its significant effects on the living activities of man. Mudukuti and Miller (2002) suggested that in the information age, dissemination of information and applying this information in the process of agricultural production will play a significant role in the development of farm settlements. In farming entrepreneurs, Doss (1999) showed that access to appropriate information has had significant impact on agricultural productivity. In the same vein, the United Nations (UN) (2002), FAO (2004), 
IFPRI (2004) and Des Castello and Braun (2006) concluded that achieving sustainable agricultural development is less based on material inputs but rather on the available knowledge and information appropriate for sharing with the farmers.

South African Agricultural Research Development (SARD, 2007) reported that there has been a steady decline in the number of rural inhabitants from $44.9 \%$ in 1996 to $42.5 \%$ in 2001 because of economic and declining agricultural opportunities in urban and rural areas respectively. The situation implies that the rural communities require information on various facets of rural livelihoods that will enhance opportunities and reduce vulnerabilities. In this regard, appropriate and scientifically researched information is needed on some of the challenges militating against good farming techniques, pest and disease control in crops and livestock, impact of climate change, storage and market hints. Appropriate agricultural information is, therefore, necessary towards helping the farmers, who are mostly the women, to satisfy their needs. However, the inequality in the distribution of resources between men and women has been linked with production inefficiency, yet interventions targeting smallholder farmers often fail to redress a women's lack of access to, and control of, important agricultural resources (Quisumbing \& Pandolfelli, 2008). Whereas, access to reliable and adequate agricultural information by women farmers could address many of their needs and aspirations and enhance production efficiency and market accessibility.

Nkonkobe Municipality has been identified as having the challenges of poverty, high unemployment rate, and poor agricultural production (Vengayi, 2009). Breaking the poverty cycle requires identifying factors militating against achieving food security and improved livelihoods among the smallholder women farmers who constitute larger percentages of rural dwellers. Most of the rural women from disadvantaged areas are using their backyards to grow crops and farm livestock in order to feed their families and the community. As little as the land size of backyard gardening may be, farmers still require agricultural information that will enhance efficient and effective utilization of the land, manage soil and water, control pests and diseases and help solve other problems emanating from the farm. Unfortunately, there is scanty information pertaining to the agricultural information needs of women farmers that could be used to design appropriate extension intervention in the municipality. This study attempts to provide answers to the following questions:

a. What are the agricultural information needs of the women farmers in Nkonkobe Municipality?

b. What are the information seeking behavioral patterns of these women farmers that add value to their farming activities?

c. What role do extension workers play in the dissemination of agricultural information to these women farmers?

\subsection{Purpose of the Study}

This study was designed to investigate the agricultural information needs of the women farmers in Nkonkobe Municipality, Eastern Cape Province, South Africa.

\subsection{The Specific Objectives}

a. Describe the demographic characteristics and agricultural information needs of the women farmers in the Nkonkobe Municipality (NM).

b. Determine the agricultural information seeking behavioral patterns of women farmers.

d. Identify channels most preferred for seeking agricultural information by the rural women farmers.

e. Determine the relevance of the obtained agricultural information towards improving agricultural productivity.

\section{Methodology}

Nkonkobe Municipality was established in 2000 with an estimated total population of 131071 and 28259 households (Global Insight, 2008). The local municipality is made up of 21 wards. According to Global Insight (2008), approximately $74 \%$ of people living within the municipal area are indigent with the majority of the population residing in both villages and in urban settlements. Urbanization is mainly concentrated in Alice and Fort Beaufort. The ratio of urbanization (Urban/rural) has improved from 4:1 in 2001 to 2:6 in 2008 (Global Insight, 2008).

The target population consisted of women farmers from ward twelve of Nkonkobe Municipality. Ward twelve is made up of nine villages comprising Ngcothoyi, Magaleni, Bergplaas, Msobomvu, Woburn, Taylor, Melani, Skhutswana, and Lower Gqumashe. Four villages were randomly selected that included Lower Gqumashe, 
Taylor, Melani and Woburn. A total of 144 copies of questionnaires was administered, but data were received and analyzed from a sample of 118 women farmers which represent $81.9 \%$ of usable questionnaires. Data was collected using the snowball technique.

\subsection{Validity and Reliability}

The instrument was field-tested for content and face validity by an expert in Information and Communication in the Department of Communication, University of Fort Hare. The instrument was pre-tested at Hala village for reliability and validation. The internal consistency reliability result was 0.79 using the Cronbach's coefficient.

The instrument for analysis was made up of two parts. Part A addressed the demographic characteristics of the women farmers that elicited information on age, marital status, level of education, source of income, size of households and main farming occupation. Part B of the questionnaire elicited information on the types of agricultural information needs that will enhance agricultural productivity, most desired channels for seeking information, information-seeking behavioral pattern, ways that the agricultural information could benefit the farmers, sourcing information, the solution obtained from the sourced channels and steps taken on the problems. The structured interview schedule was used for collecting relevant quantitative data from the sampled respondents.

The data collected were analyzed using the SPSS version 20. The descriptive statistics tools used include frequency counts, percentages and means.

\section{Results and Discussion}

Table 1. Socioeconomic characteristics of respondents in the study area $N=118$

\begin{tabular}{lll}
\hline Age & Frequency & $\%$ \\
\hline $25-35$ & 9 & 7.6 \\
$36-45$ & 36 & 30.5 \\
$46-55$ & 46 & 39.0 \\
$56-65$ & 23 & 19.5 \\
$66-75$ & 4 & 3.4 \\
Total & 118 & 100.0 \\
\hline Marital status & & \\
Single & 43 & 36.4 \\
Married & 35 & 29.7 \\
Divorced & 12 & 10.2 \\
Widow/widower & 28 & 23.7 \\
Total & 118 & 100.0 \\
\hline Number in household & & \\
$2-3$ & 48 & 40.7 \\
4-5 & 57 & 48.3 \\
6-7 & 13 & 11.0 \\
Total & 118 & 100.0 \\
\hline Education & & \\
Primary & 3 & 2.5 \\
Some secondary & 103 & 87.3 \\
Completed grade 10 & 9 & 7.6 \\
Completed grade 12 & 3 & 2.5 \\
Total & 118 & 100.0 \\
\hline Source of income & & \\
Salary & 46 & 39.0 \\
Pension, social grant & 55 & 46.6 \\
Self employed & 17 & 14.4 \\
Total & 118 & 100.0 \\
\hline
\end{tabular}

Source: Field Survey 2012. 
The descriptions of the demographic profile of the women farmers described in Table 1 indicate that many of the women farmers fell between age brackets of 46-55 years old (39\%), followed by $36-45$ years (30.5\%), and 56-65 years $(19.5 \%)$ SD (0.954). The marital status revealed those who are single as $(36.4 \%)$, married $(29.7 \%)$, widowed/ widowers $(23.7 \%)$ and the divorced $(10.2 \%)$. The number of households was highest for respondents with 4-5 children (48.3\%), followed by $2-3$ children $(40.7 \%)$ and $6-7$ children $(11.0 \%)$, SD (0.658). The educational status revealed that the majority $(87.3 \%)$ had some secondary school education but could not complete grade 10. This is followed by those who completed grades 10 and 12 which are $7.6 \%$ and $2.5 \%$ respectively. Very few (2.5\%) had only primary school education, and SD (0.441). Many of the respondents (46.6\%) depend on pension and one form of social grants such as sources of primary income; $39 \%$ were earning salaries for jobs ranging from nanny to junior staff and complementing it with farming. This is followed by $14.4 \%$ that are self-employed.

Table 2. Farming occupation

\begin{tabular}{lll}
\hline & Frequency & $\%$ \\
\hline Livestock & 3 & 2.5 \\
Backyard gardening & 22 & 18.6 \\
Indigenous chickens & 12 & 10.2 \\
Livestock and backyard garden & 16 & 13.6 \\
Backyard garden and indigenous chickens & 62 & 52.5 \\
Livestock, backyard garden and indigenous chickens & 3 & 2.5 \\
Total & 118 & 100.0
\end{tabular}

Source: Field Survey 2012.

Table 2 indicates that backyard gardening $(87.2 \% ; \mathrm{n}=103)$ was a common farming practice. A substantial number $(65.2 \% ; \mathrm{n}=77)$ kept indigenous chicken while livestock $(18.6 \% ; \mathrm{n}=22)$ mainly cattle, pigs, sheep and goat are, also, reared. The rearing of indigenous chicken by women contributes significantly to food security of the rural livelihood, and this finding was, also, reported by Gondwe (2004).

Table 3. Types of agricultural information needed

\begin{tabular}{lll}
\hline & Frequency & $\%$ \\
\hline Insects attack on vegetables e.g. Cabbage & 83 & 70.30 \\
Rust of Spinach & 37 & 31.36 \\
Weed control and management, especially when organic manure & 95 & 80.5 \\
(Cow dung) was applied & 29 & 24.58 \\
Seed dormancy problem during winter & 18 & 15.25 \\
Sudden death of chicks after hatching & 23 & 19.49 \\
Mice and Giant rat menace & 48 & 40.68 \\
Fowls predator problem & 53 & 44.91 \\
Expensive feeds for the scavenging fowls & 18 & 15.25 \\
Lice and mite problem in fowls & 32 & 27.12 \\
Soil fertility management & 49 & 66.95 \\
Fowl theft & 16 & 13.56 \\
Kid mortality in goats & 28 & 23.73 \\
Diarrhea problem in goat kids & & \\
\hline
\end{tabular}

Source: Field survey 2012.

The information needs of the women farmers varied as it was determined by the types of farming enterprises. Table 3 indicates that weed, $(80.5 \% ; \mathrm{n}=95)$ constitute a major challenge especially when cow dung was used as fertilizing materials. Some farmers $(27.12 \% ; n=32)$ whose soils require replenishing actually made use of cow 
dungs that are relatively available and cheap. The major challenge of tackling the growth of undigested weed seeds constitutes menace. Most of the farmers $(24.58 \% ; n=29)$ that depend on planting seeds of vegetables directly during winter experienced poor and late germination. This could be attributed to the dormant nature of the seeds and the climatic condition prevailing. Sudden death of chicks $(15.25 \% ; \mathrm{n}=18)$, mice and giant rats attack $(19.49 \% ; \mathrm{n}=23)$, lice and mites $(15.25 \% ; \mathrm{n}=18)$, fowl theft $(66.95 \% ; \mathrm{n}=49)$ and fowl predators $(40.68 \% ; n=48)$ were common problems for the scavenging birds. The report indicates a threat to food security of the resource-poor farmers considering the small number of flocks kept for household consumption. Most $(44.91 \% ; \mathrm{n}=53)$ who gave supplementary feeds complaint about the high cost of feeds for newly hatched chicks with the mother hens in brooding. Artificial brooding is practiced amongst some farmers to reduce predators' attack. Insect pests of vegetables $(70.3 \% ; \mathrm{n}=83)$ constituted another major problem. The farmers reported insects eating the leaves of cabbage, spinach and carrot thereby reducing yield and affecting the quality.

Table 4. Channels used mostly for obtaining Agricultural information

\begin{tabular}{lll}
\hline Channels & Frequency & $\%$ \\
\hline Radio & 1 & 0.8 \\
Extension workers & 21 & 17.8 \\
Radio and extension workers & 20 & 16.9 \\
Radio, extension workers and demonstration & 29 & 24.6 \\
Ext workers, practical farm demonstrations and group & 9 & 7.6 \\
meetings & & 38 \\
Extension and practical farm demonstrations & 118 & 100.0 \\
Total & & \\
\hline
\end{tabular}

Source: Field survey 2012.

The information-seeking pattern of the women farmers was chiefly influenced by the technical knowledge of the source coupled with practical farm demonstrations. Table 4 indicates that the importance of extension workers serving as a channel of information was noted with overwhelming responses in all variables when calculated $(99.1 \% ; n=117)$. The majority of the respondents believed that access to agricultural information through the extension workers supported with farm demonstrations will facilitate their learning thereby improving agricultural productivity.

The yearning for extension workers by the women farmers indicated the need for the government to employ more extension workers while the services of the nongovernmental organizations (NGOs) and private organizations that provide extension services are essential most especially at the village levels.

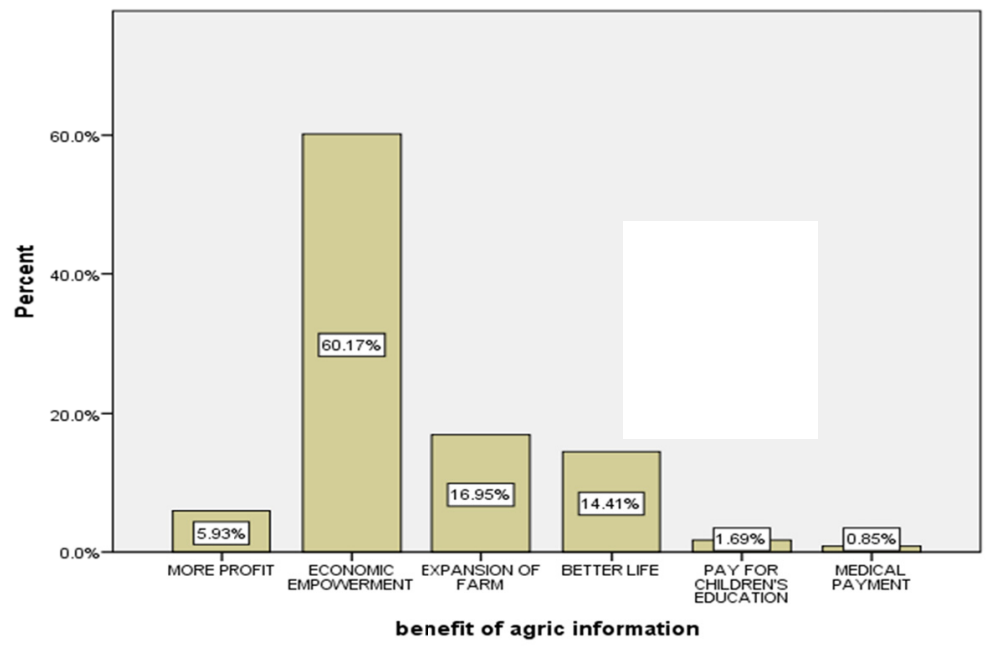

Figure 1. Frequency distribution of benefits of Agricultural information 
Figure 1 showed that the majority of the respondents $(60.2 \%)$ was of the opinion that accessing vital agricultural information will lead to their being economically empowered. This is followed by farm expansion $(16.9 \%)$ and better life (14.4\%). Other variables were believed to have been encompassed within economic empowerment framework. The women farmers believed that economic empowerment is an all embracing economic, social, cultural and political activities that make them to be relevant and recognized in the community. To them, being economically empowered implied that they are able to support their households with nutritious foods, good education, health care, and comfortably perform their social functions.

Table 5. Sources of information used by the respondents

\begin{tabular}{lll}
\hline Information sources & Frequency & $\%$ \\
\hline Husband & 1 & 0.8 \\
Friends & 30 & 25.4 \\
Neighbor & 27 & 22.9 \\
Extension agents & 8 & 6.8 \\
Farmers organizations & 3 & 2.5 \\
Cooperative Society & 2 & 1.7 \\
Farmer's colleagues & 7 & 5.9 \\
Nobody & 14 & 11.9 \\
Don't know who to contact & 21 & 17.8 \\
Where I bought inputs & 1 & 0.8 \\
University community engagement & 4 & 3.4 \\
Total & 118 & 100.0 \\
\hline
\end{tabular}

Source: Field survey 2012.

Table 4 showed that the majority of the farmers $(54.2 \% \mathrm{n}=64)$ depended on friends, neighbors and farmers' colleagues for agricultural information when faced with challenges on the farm. While $17.8 \%$; $(n=21)$ of the women farmers did not know who to contact, $(11.9 \% ; \mathrm{n}=14)$ indicated they have contacted nobody for information, only $6.8 \% ;(n=8)$ had contact with extension services, and $3.4 \% ; n=4$ sought information from the University community engagement officials. The trend where farmers relied on friends, neighbors and farmers' colleagues were also observed by Yahaya (2002), Tologbonse et al. (2006), Okwu and Dauda (2011), Achugbe and Anie (2011) and Rezvanfar et al. (2007) indicating the strong social dynamics of 'across the fence' contact when in need or facing challenges. The ease or proximity of the source could also be an enabling factor here. The low number of contacts with extension workers may be attributed to the inadequate number of extension workers operating in the municipality. Meanwhile, the findings indicate the importance of farmer-to-farmer extension model in technology dissemination. This model has proven for its potency in filling the extension gap in technology transfer to farmers in Nigeria (Kormawa, Ezedinma, \& Singh, 2004). The authors identified that the model narrowed the gap with the technology transfer process among farmers. This was attributed to the participatory role of farmers in testing, watching and circulating information among themselves that ensured adoption. However, the little contact enjoyed by the women farmers from the extension agents and university community engagement yielded positive results.

\section{Conclusion and Recommendations}

Access to adequate, relevant and reliable agricultural information is an essential factor towards building a strong and virile agricultural foundation. The significant role played by women in food security requires that they receive support towards access to scientific and unbiased agricultural information. Women farmers had been classified to be highly vulnerable due to multiple challenges they faced in the rural setting. The challenges are surmountable if they could access the right types of agricultural information as this will reduce shocks that are inherent in vulnerability context.

This study indicates that most women farmers engaged in backyard farming and indigenous chicken production. They require agricultural information that is proven towards addressing multiple challenges on their farms and 
livestock rearing. The study revealed that most farmers relied on their friends and neighbors for agricultural information. It is recommended that further study is needed towards understanding the farmer-to-farmer model of technology transfer that could be used to reach the small scale women farmers in South Africa.

\section{References}

Achugbue, E. I., \& Anie, S. O. (2011). ICTs and information needs of female farmers in Delta State, Nigeria. Library Philosophy and Practice (e-journal) paper 448. Retrieved April 8, 2012, from http://digitalcommons.unl.edu/libphilprac/448

Banji, O. A., \& Okuade, E. S. (2005). Women in agriculture and rural development. Agricultural information needs of women farmers in Mubi region. Adamawa State Journal of Tropical Agriculture, 45(1-2), 69-71.

Belkin \& Pao (1989). The development of strategies for dealing with the information needs of urban residents. Seattle. WA, University of Washington.

Bill and Melinda Gates Foundation. (2012). Addressing women's needs in agricultural work.

Department of Agriculture (DoA). (2008). The state of extension and advisory service within the Agricultural public service: A need for recovery.

Des Castello, R., \& Braun, P. M. (2006). Framework on effective rural communication for development. FAO/GTZ. Food and Agriculture Organization of the United Nations, Rome.

Doss, C. R. (1999). Twenty-Five Years of Research on Women Farmers in Africa: Lessons and Implications for Agricultural Research Institutions; with an Annotated Bibliography. CIMMYT Economics Program Paper No. 99-02. Mexico D.F.: CIMMYT

Food and Agricultural Organization (FAO). (2004). World Food Security: A Reappraisal of the Concepts and Approaches. Director General's Report. Rome.

Food and Agricultural Organization (FAO). (2011). The State of Food and Agriculture: Women in Agriculture, Closing the Gender Gap for Development. Rome.

Global Insight. (2008). Nkonkobe Municipality Annual Report, Financial year 2009-2010.

Gondwe, T. N. P. (2004). Characterization of local chicken in low input-low output production systems: is there scope for appropriate production and breeding strategies in Malawi? ( $\mathrm{PhD}$ thesis, Georg-August-Universität Göttingen, Germany).

IFPRI (International Food Policy Research Institute). (2005). The future of small farms: Proceedings of a research workshop, Wye, UK, June 26-29, 2005, Washington, DC.

Kaske, D. K. (2007). Agricultural information networks of farm women and role of agricultural extension: the case of Dale Woreda, Southern Nations, Nationalities and Peoples' Region. MSc thesis (Rural Development and Agricultural Extension). 141p. Haramaya (Ethiopia): Haramaya University.

Kormawa, P. M., Ezedinma, C. I., \& Singh, B. B. (2004). Factors influencing Farmer-to-Farmer Transfer of an improved Cowpea Variety in Kano State, Nigeria. Journal of Agriculture and Rural Development in the Tropics and Subtropics, 105(1), 1-13.

May, J., \& Carter, M. (2009). Agriculture: analysis of the NIDS Wave 1 dataset. Discussion paper no. 6, National Income Dynamics Study. Cape Town: University of Cape Town.

Mudukuti, A. E., \& Miller, L. (2002). Factors related to Zimbabwe women's educational needs in agriculture. Journal of International Agricultural and Extension Education, 9(2).

Nagdee-Hajaig, F. (2012). Empowerment of rural women ending of hunger and poverty: International treaties. Parliamentary Monitoring Group. Retrieved August 27, 2012, from http://www.pmg.org.za/report/20120307-department-health-progress-made-regard-implementation-domesti c-viol-0

Okwu, O. J., \& Daudu, S. (2011). Extension communication channels' usage and preference by farmers in Benue State, Nigeria. Journal of Agricultural Extension and Rural Development, 3(5), 88-94.

Quisumbing, A., \& Pandolfelli, L. (2008). Promising Approaches to Address the Needs of Poor Female Farmers International Food Policy Research Institute sustainable solutions for ending hunger and poverty IFPRI Note 13. 
Rezvanfar, A., Moradnezhai, H., \& Vahedi, M. (2007). Information needs of farm women related to dairy farming and home management in Ilam State of Iran. Livestock Research for Rural Development, 19(8).

Sabo, E. (2007). Agricultural information needs of women farmers in Mubi region. Adamawa State Journal of Tropical Agriculture, 45(1-2), 69-71.

Stanley, K. N. (1990). A critique of information systems and services in Kenya and the role of Kenya National Library Services in their cooperation. Adamawa State Journal of Tropical Agriculture, 45(1-2), 69-71

Tologbonse, E. B., Mesini, O., Tsado, J. H. (2006). Farmer's perception of sources of information in relation to adoption of improved technology by farmers in inland valley swamps of middle-belt zone of Nigeria. $J$. Agric. Ext., 9, 63-73.

United Nations. (2002). Best Practices for Organic Policy. What developing country Governments can do to promote the organic agriculture sector. New York. UNCTAD.

Vengayi, C. (2009). Institutional constraints to smallholder agriculture: A case study of Nkonkobe Municipality, Eastern Cape, South Africa. Unpublished Master of Science in Agriculture (Agricultural Economics) University of Fort Hare, Alice.

Yahaya, M. K. (2002). Gender and communication variables in agricultural information dissemination in two agro-ecological zones of Nigeria. Research Monograph. Ibadan: Corporate Graphics Ltd. 